\title{
Seçilmiş İslam Ülkeleri İçin Satın Alma Gücü Paritesinin Geçerliliği Üzerine Bir Çalışma
}

\author{
Mercan HATİPOĞLU*
}

ÖZ

$\mathrm{Bu}$ çalışmanın amacı seçilmiş İslam ülkeleri için satın alma gücü paritesinin (SGP) geçerliliğini tespit etmektir. Satın alma gücü paritesi döviz kurlarının fiyatlar genel seviyesi tarafından belirlendiğini savunmaktadır. Eğer parite geçerli ise döviz kurunun dengeye gelmesi için herhangi bir müdahale gerekmeyecektir. Ancak döviz kurları, birçok öngörülemeyen durumla, finansal krizler ve hükümet müdahalelerine maruz kaldıkları için, klasik birim kök testleri böyle olayları yeterince modellemekte başarısız olmaktadır. Bu yüzden ekonomi politikalarından sorumlu kurum ya da kişiler SGP'nin geçerli olup olmadığına karar verirken tereddüt yaşamaktadır. Markov rejim değiştirme modelinin, döviz kurlarını yükselirken ve düşerken aynı anda analiz edebildiği için literatürde klasik testlere göre daha iyi sonuçlar verdiği kanıtlanmıştır. Bu çalışmada Markov rejim değiştirme testleri kullanılarak Malezya ve Endonezya için SGP'nin geçerli olduğu bulunmuştur. Öte yandan bulgular Fas ve Birleşik Arap Emirlikleri'nde SGP'nin lehine kanıtlar sağlayamamıştır.

Anahtar kelimeler: Satın Alma Gücü Paritesi, İslam Ülkeleri, Markov Rejim Değiştirme Modeli

JEL Sinıflandırması: C24 F31

\section{A Study on the Validity of Purchasing Power Parity for Selected Islamic Countries}

\begin{abstract}
The aim of the paper is to examine the validity of purchasing power parity (PPP) for selected Islamic countries. Purchasing power parity argues that exchange rates are determined by the general level of prices. If the parity is valid, no intervention will be required to offset the exchange rate. Since the exchange rates are exposed to unpredictable events, financial crisis and government intervention, standard unit root tests are not capable of modelling such events adequately. Therefore, the institutions or persons responsible for economic policies are hesitant to decide whether the SGP is valid or not. Markov regime switching model has been proven to give better results in the literature than in conventional tests since the exchange rate can be analyzed at rises and falls. Using a Markov switching tests in the study, we show that purchasing power parity (PPP) hypothesis holds in Malaysia and Indonesia. On the other hand, findings do not provide evidence in favour of the PPP hypothesis in Morocco and United Arab Emirates.
\end{abstract}

Keywords: Purchasing Power Parity, Islamic Countries, Markov Switching Model

JEL Classification: C24 F31

Araştırma Makalesi - Geliş Tarihi / Received: 17.10.2018 Kabul Tarihi / Accepted: 24.11.2018

Dr. Öğr. Üyesi, Çankırı Karatekin Üniversitesi, İktisadi ve İdari Bilimler Fakültesi, İşletme Bölümü, mercanhatipoglu@gmail.com, ORCID: 0000-0003-3307-5458 


\section{GİRIŞ}

SGP yaklaşımı İsveçli bilim adamı Gustav Gassel tarafından 1920'de ilk defa literatürde bahsedilmiştir. Bu yaklaşıma göre, döviz kurlarının değeri, yurtiçi-yurtdışı fiyatlar genel seviyesi oranına eşit olmalıdır. Yani yerel ülkenin fiyatlar genel seviyesini yabancı ülkenin genel fiyatlar seviyesine böldügümüzde elde edeceğimiz oran, ülkelerin döviz paritesini vermelidir. Diğer bir anlatımla reel döviz kuru bu orana eşit olmalıdır. Yapılan araştırmalara göre SGP 'den sapmalar olduğu dönemlerde, 3-5 yıl zaman aralığında paritenin fiyat seviyelerinin oranına döndüğü gözlemlenmiştir (Nusair, 2003). SGP'nin geçersiz olması demek, nominal döviz kurlarının göreceli fiyat seviyelerine uzun dönemde yaklaşmaması anlamına geldiği için, ticarete konu olan mal ve hizmet alım-satımlarından arbitraj firsatı doğmaktadır (Baharumshah ve Soon, 2012). SGP teorisinin geçerli olmamasında en önemli etken, uluslararası sermaye hareketlerinin yani hisse senedi, tahvil alım-satımını içeren portföy yatırımlarının, dış ticaret hacmini, mal ve hizmet ithalatını parasal tutar olarak aşmasıdır. Nitekim 2010 yılında günlük döviz üzerinden yapılan işlem tutarı 4 trilyon dolara ulaşmış iken, 2009 yılında yapılan dünya ticaretinin toplam değeri 12,5 trilyon civarındadır. Böyle olunca dövizin fiyatı, mal ve hizmetlerin fiyatları tarafından değil de, hisse senedi, tahvil gibi finansal yatırım araçlarının getirileri tarafından belirlenir olmuştur. Öyle ki dövizin fiyatını açıklamada faiz oranlarından daha fazla aracı kurumlar tarafından verilen alım-satım emirlerinin etkili olduğu Evans ve lyons (2002) tarafından kanıtlanmıştır. Teorinin geçersiz olmasına katkı yapan diğer faktörler ise, dış ticarete konu olmayan mal ve hizmetler, gümrük vergileri, tarifeler ve ulaştırma maliyetleri ile emek (işçi) mobilizasyonudur (Özatay, 2011: 131-158). Ayrıca satın alma gücü paritesinden sapmaları ticarete konu olan sanayiler ile ticarete konu olmayan sektörler arasında gözlemlenen verimlilik farklılıklarına bağlayan "Balassa - Samuelson" hipotezi de literatürde çokça tartışılmaktadır (Lothian ve Taylor, 2008). Döviz kurlarının uzun dönemde değer kaybetmesinin nedeni sürekli hale gelen cari açıktır. İkinci bir neden ise hükümetlerin yaptığ 1 ticarete konu olmayan yatırımlar yani sağlık ve eğitim hizmetleridir. Her iki neden de döviz talebini yükselten faktörlerdir. Nominal döviz kurlarında gözlemlenen volatilitenin de SGP'den sapmalara neden olduğu ileri sürülmüştür (Rogoff, 1996).

SGP teorisi geçerli olduğunda ise kısa dönemde fiyatlar yapışkan olduğu için, döviz kurları değerlenerek ya da değer kaybederek uzun dönemli denge fiyatına gelecektir. Böylece ekonomi politikalarından sorumlu kurumlar, herhangi bir kur atağında ya da ödemeler dengesi ile ilgili açık ve fazlalarda, döviz kuruna müdahale etmeyecekler ve uzun dönemli kurun fiyatını bildikleri için şu anki paritenin aşırı değerli ya da eksik değerli olduklarını anlayabileceklerdir (Nusair, 2008). İkinci olarak döviz kurlarına yönelik istikrar algısı (gelen şokların geçiciliği, durağan olma), dış ticareti ve yatırımları özendirmekte ve ülkelerin finansal piyasalardan daha fazla yararlanmalarına imkan tanımaktadır. Böylece finansal piyasalar daha da derinleşmekte ve birbirleriyle entegre hala gelmektedir (Soon vd., 2015).

Finansal krizler, enflasyon oranları ya da devletin ekonomiye müdahale etmesi gibi birçok neden finansal zaman serilerinin (borsa, döviz kuru, faiz vb.) rejimlerinin değişmesine, diğer bir anlatımla serinin ortalama ve varyansının önceki dönemlere göre farklılaşmasına yol açar. Böyle serilere uygulanan klasik ADF, PP gibi birim kök testleri hatalı sonuçlar verebilmektedir. Herhangi bir zaman serisinin durağan olması demek, serinin ortalama, varyans ve kendi geçmiş gözlemleri arasındaki kovaryansın sabit olması demektir. Durağan olan yahut birim kök içermeyen zaman serilerinde, seriye gelen şoklar kalıcı olmaz. Yani, $(t+$ 1) döneminde seriye gelen şokların etkisi $(t+2)$ döneminde daha da azalır. Durağan olmayan serilere gelen şokların etkisi ise hiçbir zaman bitmez ${ }^{1}$ (Brooks, 2014: 318-322).

\footnotetext{
${ }^{1}$ Detaylı matematiksel gösterim için bakınız Brooks (2014) 7.ünite
} 
Durağanlığın tespit edilmesinin önem arz ettiği finansal serilerden biri döviz kurlarıdır. Çoğu zaman reel döviz kurlarının seviye değerlerinde birim kök yoktur hipotezini (seri durağan değildir) reddetmek çok zordur. Çünkü döviz kuru serilerinde kurun değerlenmesi (appreciation) ve değer kaybetmesi (depreciation) gibi iki safha yani iki rejim vardır. Dolayısıyla iki rejimin var olduğu bir seride birim kök sınaması için rejim değişikliğini hesaba katarak modelleme yapmak daha doğru sonucu vermektedir (Bergman ve Hansson, 2005). Satın alma gücü paritesi (SGP) kapsamında değerlendirildiğinde reel döviz kurunun pariteden sapması durağan olmayan süreci, döviz kurunun kendi ortalamasına dönmesi ise durağan olan süreci yani SGP'nin geçerli olduğunu gösterir. Ülkelerarası faiz oranlarındaki farklar, enflasyon oranlarının bir ülkede düşük diğerinde yüksek olması, Bretton Woods anlaşmasının terk edilmesi, sabit döviz kurundan dalgalı döviz kuruna geçiş gibi yapısal değişimler, merkez bankası müdahaleleri döviz kurlarının rejim değiştirmesine yani durağan iken durağan olmamasına ya da tam tersine sebep olmaktadır (Kanas, 2006).

$\mathrm{Bu}$ çalışmanın amacı satın alma gücü paritesini Markov Rejim değiştirme modeli ile seçilmiş İslam ülkeleri (Malezya, Birleşik Arap Emirlikleri, Endonezya ve Fas) için test etmektir. Çalışmanın literatüre katkısı kullanılan modelin reel döviz kurunun rejim değiştirme durumunu iki aşamalı olarak (değerlenme ve değer kaybetme) dikkate alması sonucu ekonometrik anlamda daha güçlü bulgulara ulaşmasıdır. Çalışmanın bundan sonraki kısımlarında sırasıyla literatür, veri ve yöntem, bulgular ve sonuç bölümleri yer almaktadır.

\section{LITERATÜR}

SGP hakkında literatürde farklı bulguların elde edilmesine kullanılan model ile verilerin dönemi etki etmektedir. Çok uzun dönemli veriler sabit döviz kurundan dalgalı kura geçiş dönemlerini kapsadığı için sorun olurken, panel veri yöntemine başvurulduğunda ise, hipotez bütün ülkeler için ret ya da kabul edildiği için, aslında tek bir ülke için bakıldığında kabul edilebilecek hipotez reddedilmektedir (Taylor, 2003). Oldukça zengin bir literatüre sahip olan SGP hipotezi, Lee ve Yoon (2013) tarafindan 1870-1998 dönemi kapsaminda neredeyse 100 yıllık veriler ile Avusturalya, Finlandiya, İtalya, Norveç ve İsviçre için test edilmiştir. Sonuç olarak İtalya ve Finlandiya için Bretton Woods (1946-1971) döneminde SGP'nin var olduğu bulunmuştur. Avusturalya ve Norveç'te ise altın standardı (1870-1914) döneminde SGP'nin varlı̆̆ gözlemlenmiştir. Breitung ve Candelon (2005) Latin Amerika ve Asya ülkeleri kapsamında yaptıkları çalışmalarında 1994 Meksika ve 1997 Asya krizlerinin SGP' ye olan etkisini değerlendirmişlerdir. Yazarlara göre, kriz öncesine göre kurunu ABD dolarına sabitleyen Latin Amerika ülkelerinde SGP geçerli olmaz iken, dalgalı döviz kuru rejimini uygulayan Asya ülkelerinde SGP geçerliliğini korumuştur. Dolayısıyla Asya ülkeleri için SGP' den sapmalar döviz krizi habercisi olarak erken sinyal verebilmektedir. Benzer sonuçlara Asya ülkeleri için Zurbruegg ve Allsopp (2004) kointegrasyon yöntemini uygulayarak erişmişlerdir. Kanas ve Genius (2005) ise Markow Switching- ADF yöntemini kullanarak dolar/sterlin paritesinin, kurun oynaklığının düşük olduğu zaman durağan, yüksek oynaklık dönemlerinde ise durağan olmadığını göstermişlerdir. Bu çalışmanın bulguları döviz kuru volatilitesinin düşmesinin SGP paritesini geçerli hale getirebileceğini de ima etmektedir. Aloy vd., (2011) ise SGP paritesinin geçerli olmasında coğrafi yakınlığın ve iki ülke arasındaki ticaret hacminin rol oynadığını savunmuşlardır. Dal Bianco (2008) Arjantin için SGP'nin geçerli olmamasının sebebini sermaye piyasalarının gelişmemesi ve nominal gelirlerdeki dalgalanmalara bağlı olarak yatırımlardaki istikrarsızlık olarak göstermiştir. Ayrıca Arjantin'in bazı dönmelerde uyguladığı gümrük tarifeleri ve yasakların da rolü çalışmada vurgulanmıştır. Baharumshah vd., (2007) literatürde farklı sonuçların desteklenmesinin nedenleri olarak; tüketici ve üretici olmak üzere farklı fiyat endekslerinin kullanılmasını ve birim kök testlerinin zayıflığını ileri sürmüştür. Taguchi ise 
(2010) Granger - nedensellik testi sayesinde iki ülke fiyatları arasındaki değişmelerin döviz kurlarında değişime neden olduğunu iddia etmiştir. Kanas (2009) 43 gelişmekte olan ülkenin 36 'sı için, reel döviz kurunun durağan olduğu bir rejim ve durağan olmadığı başka bir rejimin varlığını kanıtlamıştır. Telatar ve Hasanov (2009) Rusya'dan kopan bağımsız devletler topluluklarında 1995-2005 aylık frekanstaki verilerle yaptıkları analiz sonucu SGP'nin geçerli olduğunu açıklamışlardır. Yine aylık veriler ile 1994-2016 arası dönem için Bahmani-Oskooee ve Wu (2018) tarafından yapılan başka bir çalışmada 34 OECD ülkesinden 18'sinde SGP'nin geçerli olduğu anlaşılmıştır. SGP hipotezini klasik birim kök testi ADF ile OPEC ülkeleri için test eden Soofi (1998) bulgularına göre bu ülkelerde SGP geçerli değildir. Yukarıda özetlenen yabancı literatürden anlaşıldığı üzere SGP'nin geçerliliği konusu bulmaca halini almıştır. Benzer durum ülkemiz için yapılan çalışmalarda da kendini göstermektedir. Örneğin Aslan ve Kanbur (2007) Türkiye'de 1982-2005 dönemi arasında SGP'nin geçerli olmadığını belirtmişlerdir. Güriş vd., (2016) ise, Ocak 1992-Mayıs 2015 dönemi aylık verileri ile doğrusal olmayan zaman serisi yöntemlerini kullanarak ülkemizde SGP'nin geçerli olduğunu savunmuşlardır.

\section{VERI VE YÖNTEM}

Çalı̧̧mada veri olarak 3 aylık ortalama reel döviz kuru endeksleri kullanılmıştır. Verilerde baz yıl 1994 olarak seçilmiş olup başlangıç değeri 100 olarak belirtilmiştir. Reel döviz kurları Uluslararası Ödemeler Bankası (BIS) tarafından yayınlanmaktadır. Bankanın nominal kur endeksleri 61 ekonomi için düzenlenmektedir. Nominal kurlar ikili döviz kurlarının geometrik ağırlıklı ortalamaları olarak hesaplanır. Bu ağırlıklar, ticari işlem akışlarından türetilmekte ve hem doğrudan ikili ticaret hem de üçüncü pazar rekabeti dikkate alınarak hesaplanmaktadır. Aynı şekilde reel kurlar, karşılaştırmalı ülkelerdeki nispi tüketici fiyatları ile ayarlanır. ${ }^{2}$ Serilerin bu şekilde olması SGP den ne kadar sapma olduğunu göstermeyeceği için, gözlemler 100'e bölünerek bire eşitlenmiş ve logaritmaları alınarak analize hazır hale getirilmiştir ${ }^{3}$. Veriler https://fred.stlouisfed.org adresinden çeyreklik frekansta elde edilmiş olup 1994 Ocak ile 2018 Nisan dönemlerini kapsamaktadır.

Çalışmada Markov - Switching modeli reel döviz kurlarında birim kök olup olmadığını tespit etmek amacıyla kullanılmışır. Kısaca modeli $x_{t}=u_{s t}+\emptyset_{s t} x_{t-1}+\varepsilon_{t}$ tarif ettiğimizde, eğer $\emptyset_{s t}$ parametresi 1 ya da 1'e yakın değer alıyorsa seri durağan değildir yani seride birim kök vardır. Eğer aynı parametre 1' den küçük değerler alıyorsa seri durağandır ve seriye gelen şokların etkisi zamanla kaybolacaktır. SGP teorisi açısından $u_{s t}$ 'nin pozitif değer taşıması yerel ülke para biriminin değer kaybettiğini (kurun yükseldiğini), $u_{s t}$ 'nin negatif değer taşıması yerel ülke para biriminin değer kazandığını (kurun düştüğünü) söylemektedir. Modelin matematiksel yazımında Bergman ve Hansson (2005) makalesinden yararlanılmıştır. Buna göre, $x_{t}$, reel döviz kurunu temsil etmek üzere, Markov-Switching AR (1) modeli aşağıdaki şekilde yazılabilir;

$$
x_{t}=u_{s t}+\emptyset_{s t} x_{t-1}+\varepsilon_{t},
$$

Burada, $\varepsilon_{t} \| s_{t} \sim N\left(0, \sigma_{s t}^{2}\right)$ dağılır ve $x_{0}$ ilk değeri sabittir. Gözlemlenemeyen rassal durum değişkeni $s_{t}, s_{t-1}$ 'in 1 veya 2 değeri alan ve iki duruma bağlı rejim değiştiren Markov süreci izliyorsa $x_{t}$ nin geçmiş gözlemlerinden bağımsızdır. Bu durum olasılık olarak denklem 2'deki gibi ifade edilir.

$$
\operatorname{Pr}\left\{s_{t}=j \| s_{t-1}=i\right\}=p_{i j}, \text { her bir } \mathrm{i} \text { ve } \mathrm{j}=1,2 \text { içindir }
$$

\footnotetext{
${ }^{2}$ Reel kur endeksinin nasıl hesaplandığına dair detaylara www.bis.org/statistics/eer.htm adresinden ulaşılabilir.

${ }^{3}$ Dönüşümün nedeni için Rogoff, K. (1996), Bergman ve Hansson (2005) bakılabilir.
} 
Markov rejim değişikliği, $\sum_{j}^{2} \rho_{i j}=1$ için $i=1,2$ koşulunu sağlar. Bu rejim değişikliği olasılıkları 2 x 2, P geçiş olasıllı̆̆ matrisi şekline denklem 3' teki gibi dönüştürülebilir.

$$
\mathrm{P}\left[\begin{array}{cc}
p_{11} & 1-p_{22} \\
1-p_{11} & p_{22}
\end{array}\right]
$$

$x_{t}$ nin zayıf durağan durumu sağlayabilmesi için gereken koşul $2 \times 2$ A matrisidir.

$$
\mathrm{A}=\left[\begin{array}{ll}
\emptyset_{1}^{2} p_{11} & \emptyset_{1}^{2} p_{21} \\
\emptyset_{1}^{2} p_{12} & \emptyset_{1}^{2} p_{22}
\end{array}\right]
$$

$\mathrm{Bu}$ matriste bütün öz değerleri birim çemberin içindedir. Burada, $x_{t}$ nin durağanlık koşulu, $x_{t-1}$ değişkeni ile gösterilen otoregresif koşulun rejim değişimi olasıllı̆ğ ile kesişmesine bağlıdır. Hatta $x_{t-1}$ değişkeninin parametresi 1'den bile büyük çıkabilir şayet, iki rejim arasında değişim olasıllı̆g yüksek ise.

İki rejimli markov modeli vektör otoregresif süreç olarak yazıldığında $\xi_{t}, 2 \times 1$ vektör olarak;

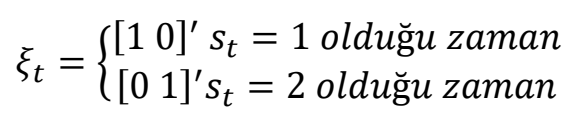

Eğer $s_{t}=1$ olursa $\xi_{t+1}$ rassal değişkeni $p_{12}=1-p_{11}$ olasıllıkla 1 değerini alır. Böylelikle $\xi_{t+1}$ parametresinin koşullu beklenen değeri $s_{t}=1$ olduğunda denklem 3'de belirtilen P matrisinin ilk sütunu olmaktadır.

$$
\mathrm{E}\left\{\xi_{t+1} \mid s_{t}=1\right\}=\mathrm{P}\left[\begin{array}{c}
p_{11} \\
1-p_{11}
\end{array}\right] .
$$

\section{BULGULAR}

İslam ülkelerinin reel döviz kurlarına ilişkin tanımlayıcı istatistikleri tablo 1'de sunulmuştur. Finans yazınında standart sapma, riski temsil ettiği için, döviz kuru riski en fazla olan ülkeler sırasıyla Endonezya ve Fas olmaktadır. Normal dağılımı gösteren JB istatistiğine göre BAE (Birleşik Arap Emirlikleri) döviz kurları normal dağılıma sahiptir. Serilerde birim kök yani durağan olmamayı kanıtlayan ADF testinin sonuçlarına göre olasılık değerleri 0.10 'dan büyük olduğu için Malezya, BAE ve Fas döviz kurlarında birim kök vardır. Endonezya'da ise 0.05 olasıllı̆a göre birim kök var iken 0.10 olasıllğa göre birim kök yoktur.

Tablo 1: Tanımlayıcı İstatistikler

\begin{tabular}{ccccc}
\hline & Malezya & Bae & Endonezya & Fas \\
\hline Ortalama & 0.004 & -0.082 & -0.141 & 0.083 \\
Std. Sapma & 0.091 & 0.120 & 0.181 & 0.121 \\
Çarpıklık & 0.975 & -0.407 & -1.749 & 1.163 \\
Basıklık & 3.717 & 2.697 & 7.138 & 4.824 \\
JB & {$[0.00]$} & {$[0.213]$} & {$[0.00]$} & {$[0.00]$} \\
ADF & {$[0.125]$} & {$[0.494]$} & {$[0.061]$} & {$[0.392]$} \\
\hline
\end{tabular}

Köşeli parantez içindeki rakamlar olasılık değerlerini göstermektedir. 
Döviz kuru serilerinde birim kökün varlığ1 Markov rejim yöntemiyle test edilmiş ve bulgular Tablo 2'de sunulmuştur. Yöntem bölümünde de anlatıldığ üzere $\emptyset$ parametresinin 1'den küçük olması serilerde birim kök olmadığını ima etmektedir. Buna göre Malezya ve Endonezya reel döviz kurlarında birim kök yok iken, BAE ile Fas ülkelerinin döviz kurlarında birim kök vardır. ADF istatistikleri ile kıyasladığımızda, Malezya için farklı bulgulara işaret edilmiştir. Markov rejim değiştirme modeline göre Malezya reel döviz kurları durağan iken ADF testine göre değildir.

Tablo 2: AR(1) Gecikmeli İki Rejimli Markov Rejim Değişimi Modellerinin Sonuçları

\begin{tabular}{ccccc}
\hline Parametre & Malezya & Bae & Endonezya & Fas \\
\hline $\boldsymbol{\mu}_{\mathbf{1}}$ & $-0.037^{* *}$ & $-0.271^{* * * *}$ & 0.059 & $0.605^{* * *}$ \\
& $(0.019)$ & $(0.021)$ & $(0.057)$ & $(0.029)$ \\
$\boldsymbol{\mu}_{\mathbf{2}}$ & $0.140^{* * *}$ & $-0.205^{* * *}$ & $-0.460^{* * *}$ & $0.292^{* * *}$ \\
& $(0.018)$ & $(0.024)$ & $(0.069)$ & $(0.047)$ \\
$\varnothing$ & $0.906^{* * *}$ & $0.100^{* * *}$ & $0.977^{* * *}$ & $0.100^{* * *}$ \\
& $(0.046)$ & $(0.009)$ & $(0.025)$ & $(0.101)$ \\
$\log \left(\boldsymbol{\sigma}^{\mathbf{2}}\right)$ & $0.2171^{* * * *}$ & $0.2060^{* * *}$ & $0.0520^{* * * *}$ & $0.0280^{* * *}$ \\
& $(0.073)$ & $(0.079)$ & $(0.025)$ & $(0.074)$ \\
$\boldsymbol{p}_{\mathbf{1 1}}$ & 0.99 & 0.97 & 0.98 & 0.01 \\
$\boldsymbol{p}_{\mathbf{2 2}}$ & 0.97 & 0.61 & 0.66 & 0.99 \\
$\left(\mathbf{Q}^{2}\right) \mathbf{4}$ & {$[0.51]$} & {$[0.59]$} & {$[0.38]$} & {$[0.93]$} \\
$\mathbf{A R C H}-\mathbf{L M}(\mathbf{4})$ & {$[0.22]$} & {$[0.93]$} & {$[0.15]$} & {$[0.79]$} \\
\hline
\end{tabular}

Parantez içindeki sayılar standart hataları, köşeli parantez içindeki rakamlar olasıllk değerlerini göstermektedir. * $\% 1$ seviyesinde anlamlılı, **\%5 seviyesinde anlamlllk ve ***\%10 seviyesinde anlamlllk demektir.

Yine Tablo 2'de gösterildiği üzere Markov rejim modeli, döviz kurlarını iki bölgeye ayırmıştır. Sabit terimin $(\mu)$ pozitif değer aldığı yani ülke döviz kurunun yükseldiği diğer bir anlatımla, diğer ülke para birimlerine karşı değer kaybettiği rejim. Sabit terimin $(\mu)$ negatif değer aldığ1 yani ülke döviz kurunun düştüğü diğer bir anlatımla, diğer ülke para birimlerine karşı değer kazandığ rejim. SGP teorisinden pozitif bir sapma olduğunda yani yerel ülke kuru olması gerekenden fazla değer kazandığında sabit terim negatif değer alırken, negatif bir sapma olduğunda yani yerel ülke kuru olması gerekenden fazla değer kaybettiğinde sabit terim pozitif değer alır. Döviz kurunun hangi rejimde kalmasının olasılığı ise $p_{11}$ ve $p_{22}$ katsayıları ile gösterilmiştir. Olasılık grafikleri ve serinin ne zaman rejim değiştirdiği ise ekteki grafiklerde sunulmuştur. Buna göre Malezya için $\mu_{1}$ parametresi döviz kurunun değer kazandığı dönemi 
gösterirken $\mu_{2}$ parametresi döviz kurunun değer kaybettiği dönemi göstermektedir. Grafiklerde incelendiğinde Malezya ringiti 1997 Asya krizine kadar değer kazanmış (1.rejimde kalmış) ve bu krizden sonra sürekli olarak değer kaybetmeye başlamıştır (2. rejime geçmiştir). Analiz ettiğimiz dönemde Malezya için kur bir kez rejim değiştirmiştir. Bu tarih ekteki grafiklerde görüleceği üzere Asya krizi sırasına denk düşmektedir. Her iki rejimde kalma olasılıklarında yüksek olduğu için Malezya özelinde döviz kuru sık sık rejim değiştirmeyecektir. Aynı durum Endonezya için tam ters olarak geçerlidir. Endonezya rupisi Asya krizinden sonra sürekli olarak değer kazanmaya başlamıştır. Benzer biçimde Endonezya rupisi de bir kez rejim değiş̧irmiş ve uzun süre aynı rejimi sürdürmüştür. BAE ve Fas için $\emptyset$ parametresinin tam bire eşit olması bu ülkelerde döviz kurunun durağan olmadığını kanıtlamıştır. Bu demektir ki, adı geçen ülkelerde döviz kurunda gözlemlenen değişimleri enflasyon dişındaki makroekonomik değişkenlerde aramak gerekmektedir. Markov rejim değişikliği modelinin otokorelasyon ve değişen varyans bakımından sorunlu olmadığı (Q2) ve (ARCH -LM) istatistikleri ile gösterilmiştir. $\mathrm{Bu}$ istatistikler için 4. gecikme seçilmesinin nedeni serilerin çeyrek frekansta olmasıdır. Böylece 1 yıla gecikmeye kadar serilerde değişen varyans ve otokorelasyon sorunu yoktur.

\section{SONUC}

$\mathrm{Bu}$ çalışmada İslam dünyasından Malezya, BAE, Endonezya ve Fas ülkelerinde SGP teorisinin geçerli olup olmadığı araştırılmıştır. Sonuç olarak sadece Malezya ve Endonezya için SGP'nin geçerli olduğu sonucuna varılmıştır. Bu sonuç Breitung ve Candelon (2005) ile benzerlik taşımaktadır. Buna göre Malezya ringiti ve Endonezya rupisinin değeri daha çok enflasyon oranları tarafından belirlenmektedir. Bu ülkeler özelinde, fiyat seviyelerinden başka nedenler ile kurlarda yaşanan hareketler geçici nitelik taşmakta olup herhangi bir döviz müdahalesinin gereği olmadan denge seviyelerine gelecektir. İkinci olarak döviz kurlarına yönelik istikrar algısı sayesinde bu ülkelerin finansal piyasaları daha fazla derinleşme ve birbirleriyle entegre hala gelmektedir. Öte yandan, Fas için SGP' nin geçersiz olduğu sonucuna varılmıştır. Bu sonuç Pesaran vd., (2009) ile benzerlik taşırken, Holmes (2000) ile farklılık arz etmektedir. Yine Birleşik Arap Emirlikleri için SGP geçersiz olduğu sonucuna varılmıştır. Bu sonuç Hassanain (2004) tarafından tespit edilen SGP'den sapmaların ortalama süresinin 2.19 yıl olduğu bulgusunu desteklemektedir. SGP'nin geçersiz olduğu ülkelerde fiyatların, denge pariteteden sapması, ticaret yapılan ülkeler arasındaki verimlilik farklılıklarına bağlı olabilir (Wu vd., 2018). Bu çalışmada vurgulanmak istenen diğer bir bulgu, Fas ve Birleşik Arap Emirlikleri döviz kurlarında birim kök tespit edildiği için reel döviz kurlarının durağan olmadı̆̆ıdır. Dolayısıyla, bu ülke para birimlerine gelecek şoklar kalıcı şekilde döviz kurlarını düşürebilir ya da yükseltebilir. Dengenin sağlanması için para ve maliye politikalarının uygulanması gerekebilir.

\section{KAYNAKÇA}

Aloy, M., Boutahar, M., Gente, K., and Péguin-Feissolle, A. (2011). Purchasing power parity and the long memory properties of real exchange rates: does one size fit all ?. Economic Modelling, 28(3), 1279-1290.

Aslan, N. ve Kanbur, N. (2007). Türkiye'de 1980 sonrası satın alma gücü paritesi yaklaşımı. Marmara Üniversitesi I.I. B.F. Dergisi, 23(2), 9-43

Baharumshah, Z. and Soon, S. (2012). Mean reversion in bilateral real exchange rates: evidence from the malaysian ringgit. Applied Economics, 44(22), 2921-2933.

Baharumshah, Z., Aggarwal, R., and Haw, C. (2007). East asian real exchange rates and ppp: new evidence from panel-data tests. Global Economic Review, 36(2), 103-119. 
Bahman1-Oskooee, M., and Wu, T. (2018). PPP in the 34 oecd countries: evidence from quantile-based unit root tests with both smooth and sharp breaks. Applied Economics, 50(23), 2622-2634.

Bergman, U. and Hansson, J. (2005). ,Real exchange rates and switching regimes. Journal of International Money and Finance, 24(1), 121-138.

Breitung, J. and Candelon, B. (2005). Purchasing power parity during currency crises: a panel unit root test under structural breaks. Review of World Economics, 141(1), 124-140.

Brooks, C. (2014). Introductory Econometrics For Finance. (3th ed.). Cambridge University Press.

Dal Bianco, M. J. (2008). Argentinean real exchange rate 1900-2006: testing purchasing power parity theory. Estudios de Economía, 35(1), 33-64.

Evans, D. and Lyons, K. (2002). Order flow and exchange rate dynamics. Journal Of Political Economy, 110(1), 170180 .

Güriş, B., Tıraşoğlu, B. ve Tıraşoğlu, M. (2016). Türkiye'de satin alma gücü paritesi geçerli mi?: doğrusal olmayan birim kök testleri. Sosyal Bilimler Araştırma Dergisi, 5(4), 30-42.

Hassanain, K. (2004). Purchasing power parity: Further evidence and implications. Review of Middle East Economics and Finance, 2(1), 63-77.

Holmes, M. J. (2000). Does purchasing power parity hold in African less developed countries? Evidence from a panel data unit root test. Journal of African Economies, 9(1), 63-78.

Kanas, A. (2006). Purchasing power parity and markov regime switching. Journal of Money, Credit and Banking, 1669-1687.

Kanas, A. (2009). Real exchange rates and developing countries. International Journal of Finance and Economics, 14(3), 280-299.

Kanas, A., and Genius, M. (2005). Regime (non) stationarity in the us/uk real exchange rate. Economics Letters, 87(3), 407-413.

Lee, H. T., and Yoon, G. (2013). Does purchasing power parity hold sometimes? regime switching in real exchange rates. Applied Economics, 45(16), 2279-2294.

Lothian, J. R., and Taylor, M. P. (2008). Real exchange rates over the past two centuries: how important is the harrod-balassa-samuelson effect? The Economic Journal, 118(532), 1742-1763.

Nusair, S. A. (2003). Testing the validity of purchasing power parity for asian countries during the current float. Journal of Economic Development, 28(2), 129-147.

Nusair, S. A. (2008). Purchasing power parity under regime shifts: an application to asian countries. Asian Economic Journal, 22(3), 241-266.

Özatay, F. (2011). Parasal İktisat: Kuram ve Politika. Efil Yayınevi. Ankara

Pesaran, M. H., Smith, R. P., Yamagata, T., \& Hvozdyk, L. (2009). Pairwise tests of purchasing power parity. Econometric Reviews, 28(6), 495-521.

Rogoff, K. (1996).The purchasing power parity puzzle. Journal of Economic Literature, 34(2), 647-668.

Soofi, A. S. (1998). A fractional cointegration test of purchasing power parity: the case of selected members of opec. Applied Financial Economics, 8(6), 559-566.

Soon, S. V., Baharumshah, A. Z., and Ahn, S. K. (2015). Real exchange rate dynamics in the asian economies: can regime shifts explain purchasing power parity puzzles? . Global Economic Review, 44(2), 219-236.

Taguch, H. (2010). The pre-and post-crisis real exchange rate behavior in selected east asian countries. Studies in Regional Science, 40(1), 27-40.

Taylor, M. P. (2003). Purchasing power parity. Review of International Economics, 11(3), 436-452.

Telatar, E., ve Hasanov, M. (2009). Purchasing power parity in transition economies: evidence from the commonwealth of independent states. Post-Communist Economies, 21(2), 157-173.

NZurbruegg, R., and Allsopp, L. (2004). Purchasing power parity and the impact of the east asian currency crisis. Journal Of Asian Economics, 15(4), 739-758.

Wu, J., Bahmani-Oskooee, M., and Chang, T. (2018). Revisiting purchasing power parity in G6 countries: an application of smooth time-varying cointegration approach. Empirica, 45(1), 187-196. 


\section{Ek: Rejim Olasılık Grafikleri}

Malezya

BAE

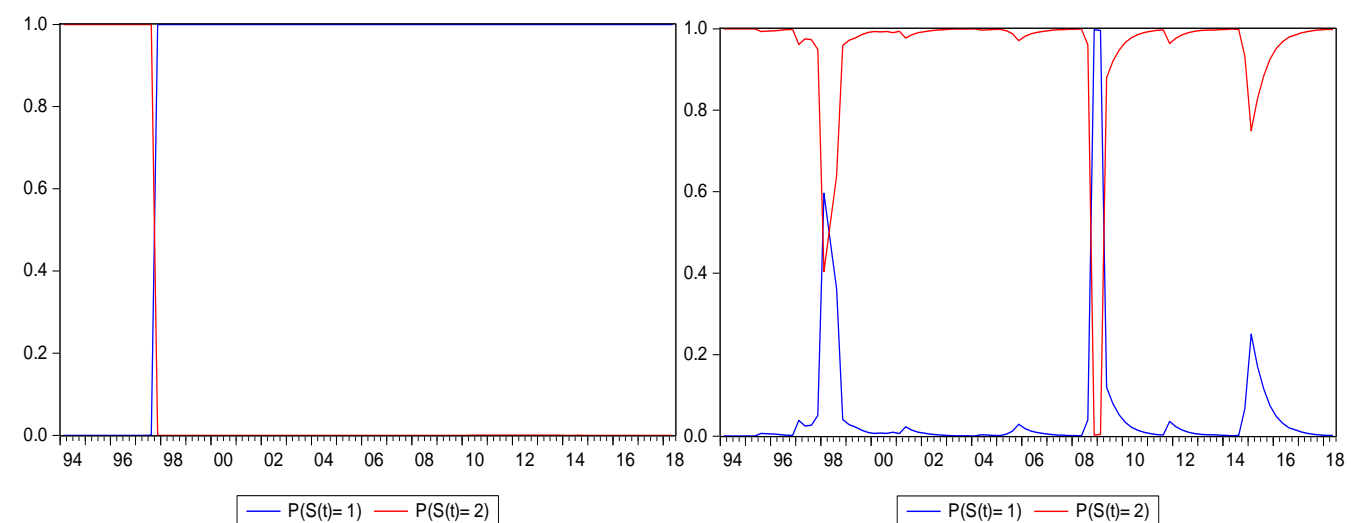

Endonezya

Fas

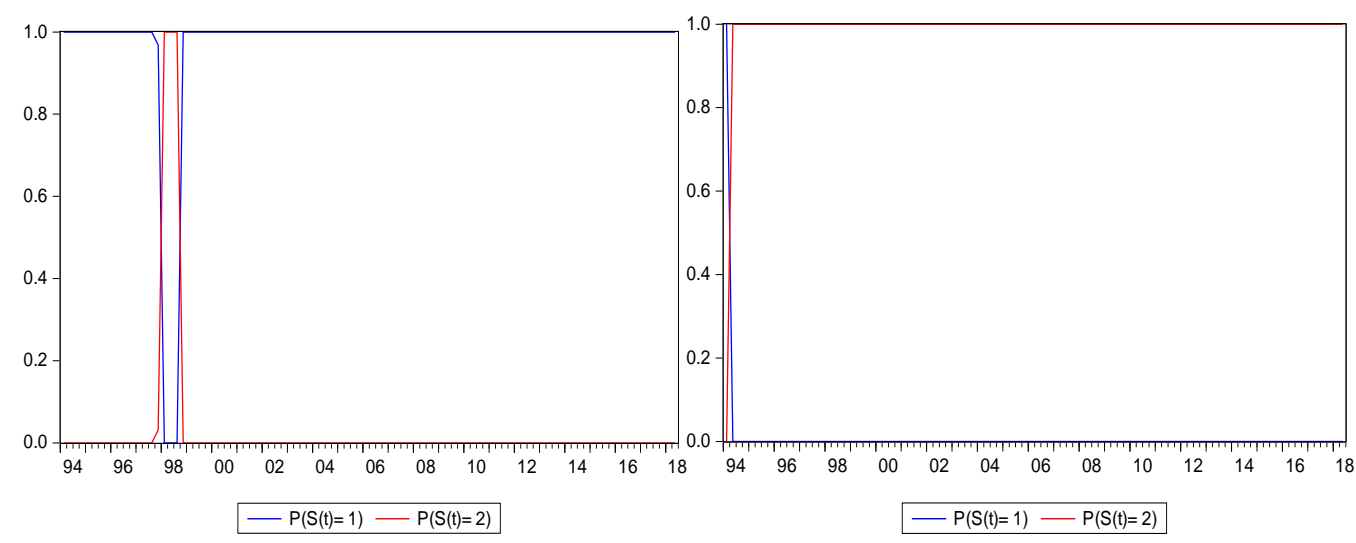


Optimum Journal of Economics and Management Sciences, Vo1. 6, No. 1- http://dergipark.gov.trloptimum/ Hatipoğlu - A Study on the Validity of Purchasing Power Parity for Selected Islamic Countries 